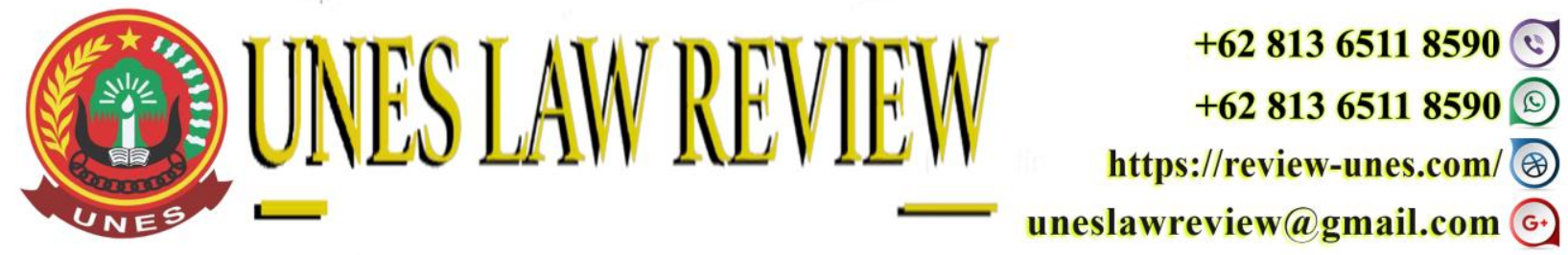

DOI: https://doi.org/10.31933/unesrev.v4i1

Diterima: 24/09/2021, Diperbaiki: 07/10/2021, Diterbitkan: 20/10/2021

\title{
PELAKSANAAN HAK KLIEN PEMASYARAKATAN UNTUK MEMPEROLEH BIMBINGAN DI BALAI PEMASYARAKATAN KLAS I PADANG
}

\section{Retno Rahman}

Program Magister Ilmu Hukum, Universitas Ekasakti, Padang, Indonesia.

Email: asrijoni1@gmail.com

Corresponding Author: Retno Rahman

\section{ABSTRACT}

One of the goals of the Correctional System is to prepare Correctional Inmates (WBP) or hereinafter referred to as Correctional Clients so that they can integrate in a healthy manner and play a responsible role again in the family and the wider community. Class I Correctional Center Padang as a Technical Implementation Unit from the Ministry of Law and Human Rights of West Sumatra as a law enforcer who carries out duties in the field of guiding Correctional Clients who must carry out correctional duties and functions based on applicable legal rules so that the fulfillment and protection of Human Rights can be realized. The fulfillment of the client's rights is regulated in the Law of the Republic of Indonesia Number 12 of 1995 concerning Corrections and the rules for its implementation.

Keywords: Correctional System, Client Guidance

\section{ABSTRAK}

Salah satu tujuan sistem Pemasyarakatan adalah menyiapkan Warga Binaan Pemasyarakatan (WBP) atau selanjutnya disebut Klien Pemasyarakatan agar dapat berintegrasi secara sehat dan berperan kembali dalam keluarga dan lingkungan masyarakat luas secara bertanggung jawab. Balai Pemasyarakatan Klas I Padang Sebagai Unit Pelaksana Teknis Dari Kementerian Hukum dan HAM Sumatera Barat sebagai penegak hukum yang melaksanakan tugas di bidang pembimbingan Klien Pemasyarakatan yang harus melaksanakan tugas dan fungsi pemasyarakatan dilandaskan pada aturan hukum yang berlaku agar pemenuhan dan perlindungan Hak Asasi Manusia dapat direalisasikan. Pemenuhan hak klien diatur dalam Undang-undang Republik Indonesia Nomor 12 Tahun 1995 tentang Pemasyarakatan dan aturan pelaksanaannya.

Kata Kunci: Sistem Pemasyarakatan, Pembimbingan Klien 


\section{PENDAHULUAN}

Salah satu tujuan sistem Pemasyarakatan adalah $^{1}$ menyiapkan Warga Binaan Pemasyarakatan (WBP) atau selanjutnya disebut klien pemasyarakat-an agar dapat berintegrasi secara sehat dan berperan kembali dalam keluarga dan lingkungan masyarakat luas secara bertanggung jawab. Permasalahan terjadi tidak hanya dalam lapas saja tetapi juga permasalahan yang dihadapi setelah keluar dari lapas dan menjadi bagian dari masyarakat. Banyak mantan napi yng tidak berapa lama bebas kembali menjadi residivis. Hal ini dikarenakan keretakan hubungan antara mantan napi dan masyarakat tidak diselesaikan dengan baik sehingga ketika napi bebas, dia belum tentu bisa diterima di lingkungan masyarakat dan pada akhirnya kembali berbuat kejahatan. Disinilah "Pemasyarakatan" berperan "memasyarakatkan" seorang napi. Mengingat tujuan pemasyarakatan adalah reintegrasi sosial guna mencapai kesatuan hubungan hidup. Kehidupan dan penghidupan maka pembinaan yang diberikan di LAPAS seharusnya tidak hanya berguna atau berfungsi di dalam LAPAS saja tetapijuga semestinya sampai napi keluar menjadi bagian dari masyarakat.

Untuk memasyarakatkan seorang napi diperlukan pembinaan, pembinaan disini tidak hanya peran BAPAS yang berperan tapi juga diperlukan peran masyarakat. reintegrasi sosial yang berasumsi bahwa kejahatan adalah konflik yang terjadi antara pelaku kejahatan dengan masyarakat. Sehingga hukuman (pidana) yang diberikan ditujukan untuk memulihkan konflik atau menyatukan kembali terpidana dengan masyarakatnya. Oleh karena itulah, idealnya masyarakat memegang peranan penting dalam hal proses kembalinya narapidana ke tengahtengah lingkungannya. ${ }^{2}$

Peran Balai Pemasyarakatan secara spesifik dalam pemasyarakatan adalah memberikan pembimbingan kepada klien pemasyarakatan, tugas inilah yang membedakan dengan unit lainnya di pemasyarakatan dalam mewujudkan fungsi sistem pemasyarakatan.

Dalam proses pembimbingan, ${ }^{3}$ prinsip merupakan merupakan pedoman dalam melakukan aktivitas pembimbingan, pendampingan serta pengawasan sebagaimana amanat peraturan perundang-undangan. Oleh karena itu prinsip-prinsip dasar ini perlu dipahami oleh Pembimbing Kemasyarakatan agar dapatmelaksanakan pembimbingan terhadap klien pemasyarakatan secara optimal. Demikian pula teknik sangat penting agar metode dapat diimplementasikan dengan menggunakan teknik yang tepat sesuai dengan permasalahan dan kebutuhan klien pemasyarakatan, sehingga tujuan sistem pemasyarakatan dapat tercapai.

Balai Pemasyarakatan Klas I Padang Sebagai Unit Pelaksana Teknis Dari Kementerian Hukum dan HAM Sumatera Barat sebagai penegak hukum yang melaksanakan tugas di bidang pembimbingan Klien Pemasyarakatan yang harus melaksanakan tugas dan fungsi

\footnotetext{
${ }^{1}$ Naskah Akademik Ruu Tentang Perubahan Atas Undang-UndangNomor 12 Tahun 1995 Tentang Pemasyarakatan, Pusat Perencanaan Pembangunan HukumNasionalBadan Pembinaan Hukum NasionalKementerian Hukum Dan Hak Asasi Manusia2013, hlm. 9.

${ }^{2}$ Ibid, hlm. 10.

${ }^{3}$ Dede Erni Kartikawati, Dasar-Dasar Pembimbingan, Modul Latihan Dasar Calon Pembimbing Kemasyarakatan Pertama, Badan Pengembangan Sumber daya ManusiaKementerian Hukum Dan HAM Republik Indonesia Tahun 2016.
} 
pemasyarakatan dilandaskan pada aturan hukum yang berlaku agar pemenuhan dan perlindungan Hak Asasi Manusia dapat direalisasikan.

\section{METODE PENELITIAN}

Metode penelitian yang digunakan dalam penelitian tesis ini adalah sebagai berikut:

\section{Spesifikasi Penelitian}

Penelitian dalam rangka penyusunan tesis ini termasuk dalam penelitian deskriptif, dimana penulis harus mengumpulkan data primer dan sekunder serta mengkonstruksikannya ke dalam suatu rangkaian hasil penelitian.

2. Metode Pendekatan

Metode pendekatan yang digunakan dalam penelitian ini adalah pendekatan yuridis normatifsebagai pendekatan utama yang didukung oleh pendekatan yuridis empiris. Penelitian dengan pendekatan yuridis normatif digunakan untuk menganalisis kaedah-kaedah hukum yang ada dalam data hukum yang berkaitan dengan pengaturan dan pelaksanaan kewenangan dari Balai Pemasyarakatan dalam pembimbingan Klien Pemasyarakatan, dalam rangka menemukan asas-asas dan konsep serta dasar-dasar pemikiran yang berhubungan dengan penelitian ini.Sedangkan pendekatan yuridis empiris dilakukan untuk praktek-praktek pengaturan dan kewenangan dari Balai Pemasyarakatan sesuai dengan kaedah-kaedah hukum yang berlaku.

\section{HASIL DAN PEMBAHASAN}

Pelaksanaan Terhadap Hak Klien Pemasyarakatan Untuk Memperoleh Bimbingan Di Balai Pemasyarakatan Klas I Padang

Pembinaan yang dilaksanakan terhadap narapidana disesuaikan dengan asas-asas yang terkandung dalam Pancasila, Undang-undang Dasar 1945 dan Standard Minimum Rules (SMR) yang tercermin dalam 10 Prinsip Pemasyarakatan. Pemasyarakatan merupakan bagian akhir dari sistem pemidanaan dalam tata peradilan pidana adalah bagian integral dari tata peradilan terpadu (Integral Justice System) Dengan demikian, Pemasyarakatan baik ditinjau dari sistem kelembagaan, cara pembinaan dan petugas pemasyarakatan, merupakan bagian yang tak terpisahkan dari satu rangkaian proses penegakan hukum dengan memperhatikan tegaknya hak asasi manusia (HAM).

Undang - Undang Nomor 12 Tahun 1995 Tentang Pemasyarakatan penjelasan Pasal 5 huruf c dan d berbunyi: "Yang dimaksud dengan pendidikan dan pembimbingan adalah bahwa penyelenggara pendidikan dan pembimbingan dilaksanakan berdasarkan Pancasila antara peranan jiwa, kekeluargaan, keterampilan, pendidikan, kerohanian dan kesempatan untuk menunaikan ibadah." Sedangkan penjelasan Pasal 7 ayat 2 berbunyi: "Pembinaan dan Pembimbingan Warga Binaan Pemasyarakatan meliputi program pembinaan dan pembimbingan

\footnotetext{
${ }^{4}$ Penny Naluria Utami, Keadilan Bagi Narapida di Lembaga Pemasyarakatan, Jurnal Penelitian Hukum DE JURE, Volume 17, Nomor 3, September 2017, hlm. 387
} 
yang berupa kegiatan pembinaan kepribadian dan pembinaan mental dan watak agar Warga Binaan Pemasyarakatan menjadi manusia seutuhnya bertaqwa dan bertanggung jawab kepada diri sendiri, keluarga dan masyarakat."

Peraturan Pemerintah Nomor 32 Tahun 1999 tentang Syarat dan Tata Cara Pelaksanaan Warga Binaan Pemasyarakatan Pasal 1 angka 5 berbunyi:

Pembimbingan adalah pemberian tuntutan untuk meningkatkan kualitas ketaqwaan terhadap Tuhan Yang Maha Esa, Intelektual, sikap dan prilaku, kesehatan jasmani dan rohani klien pemasyarakatan.

Peraturan Menteri Hukum dan HAM Nomior 21 Tahun 2013 Tentang Syarat dan Tata Cara Pelaksanaan, Asimilasi, Pembebasan Besyarat, Cuti Menjelang Bebas dan Bebas Bersyarat Pasal 1 angka 14 berbunyi:

Pembimbingan adalah pemberian tuntutan unyuk meningkatkan kualitas ketaqwaan kepada Tuhan Yang Maha Esa, intelektual, sikap dan prilaku, kesehatan jasmani dan rohani klien.

Peraturan Pemerintah (PP) Nomor 31 Tahun 1999 tentang Pembinaan dan Pembimbingan Warga Binaan Pemasyarakatan Pasal 1 menyebutkan :

Pembimbingan merupakan pemberian tuntunan untuk meningkatkan kualitas kataqwaan terhadap Tuhan Yang Maha Esa, Intelektual, sikap dan perilaku, profesional, kesehatan jasmani dan rohani, klien pemasyarakatan.

Menurut beberapa penjelasan tersebut dapat disimpulkan bahwa pembimbingan merupakan pemberian tuntutan untuk memperbaiki kepribadian dan mental seseorang serta meningkatkan ketaqwaan terhadap Tuhan Yang Maha Esa, sikap dan prilaku, kesehatan rohani dan jasmani.Bimbingan yang diberikan di BAPAS disalurkan melalui Pembimbing Kemasyarakatan. Pembimbing Kemasyarakatan akan memberikan bimbingan kemasyarakatan. Bimbingan kemasyarakatan adalah upaya yang dilakukan oleh pembimbing Kemasyarakatan dalam menghindari terjadinya pengulangan kembali pelanggaran hukum yang dilakukannya. ${ }^{5}$

Berdasarkan Undang-Undang Nomor. 12 Tahun 1995, Pasal 6 Ayat (3) dan Peraturan Menteri Hukum dan HAM RI Nomor M.2.PK.04-10 Tahun 2007 Pasal 16 (2), sasaran pembimbingan yang dilakukan oleh Balai Pemasyarakatan adalah :

1. Terpidana bersyarat.

2. Narapidana Anak Pidana dan anak Negara yang mendapat pembebsan bersyarat atau cuti menjelang bebas.

3. Anak Negara yang berdasarkan putusan pengadilan, pembinaannya diserahkan kepada orang tua asuh atau badan sosial.

4. Anak Negara yang berdasarkan Keputusan Menteri atau pejabat di lingkungan Direktorat Jenderal Pemasyarakatan yang di tunjuk, bimbingannya diserahkan kepada orang tua asuh atau badan sosial.

5. Anak yang berdasarkan penetapan pengadilan, bimbingannya dikembalikan kepada orang tuanya atau walinya.

\footnotetext{
${ }^{5}$ Maidin Gultom, Perlindungan Hukum Terhadap Anak dan Perempuan, PT Refika Aditama, Bandung, 2012, hlm. 182
} 
Mengenai teknis pelaksanaan bimbingan terhadap klien pemasyarakatan diatur dalam pasal 10 Keputusan Direktur Jendral Pemasyarakatan No.E.06-PK.04.10 Tahun 1992 Tentang Petunjuk Pelaksanaan Asimilasi, Pembebasan Bersyarat dan Cuti Menjelang Bebas, yaitu sebagai berikut:

1. Pelaksanaan Pembebasan bersyarat narapidana adalah Jaksa pada Kejaksaan Negeri di wilayah hukum Lembaga Pemasyarakatan tempat narapidana yang bersangkutan menjalani pidana;

2. Apabila narapidana menjalankan masa pembebasan bersyarat bukan diwilayah hukum jaksa yang melaksanakan, maka dalam jangka waktu 7 hari setelah tanggal pelaksanaan, narapidana tersebut harus melapor ke Kejaksaan Negeri ditempat ia menjalani masa pembebasan bersyaratnya dengan memperlihatkan buku bebas bersyarat yang diterimanya dan diantar oleh petugas Balai Bimbingan Kemasyarakatan dan Pengentasan Anak;

3. Narapidana yang akan melaksanakan pembebasan bersyarat diserah terimakan oleh Kepala Lembaga Pemasyarakatan kepada Kepala Balai Bimbingan Kemasyarakatan dan pengentasan Anak yang akan memberikan bimbingan dengan menggunakan Berita Acara Serah Terima Formulir APC-11disertai risalah singkat pembinaannya;

4. Bimbingan terhadap narapidana dilaksanakan oleh Balai Pemasyarakatan melalui program bimbingan dengan memperhatikan pertimbangan Tim Pengamat Pemasyarakatan (TPP) Balai Pemasyarakatan.

Pembebasan bersyarat merupakan bagian dari fungsi Lembaga Pemasyarakatan, yang merupakan salah satu dari bagian sistem peradilan pidana Indonesia, yaitu Kepolisian, Kejaksaan, dan Pengadilan. ${ }^{6}$ Ketentuan mengenai pembebasan bersyaratdi dalam peraturan perundang-undangan Indonesia, pertama kalinya termuat dengan istilah pelepasan bersyarat di dalam KUHP, dimana penyusunan KUHP dibuat berdasarkan Wetboek van straftrecht voor Nederlandsch-Indie, yang Hukum Pidana itu sendiri. ${ }^{7}$ Keberadaan ketentuan pelepasan bersyarat dalam Wetboek van straftrecht voor Nederlandsch-Indie terpengaruh oleh sistem pidana penjara di Inggris (progressive system), dimana pembebasan bersyarat tersebut dimaksudkan sisa pidana terakhir dalam rangka pengembalian terpidana dengan baik ke masyarakat. ${ }^{8}$

Pembebasan bersyarat, merupakan pembinaan narapidana yang menitik-beratkan pada penyatuan dengan masyarakat atau berbasiskan masyarakat. Narapidana selain individu juga anggota masyarakat, dalam pembinaannya tidak boleh diasingkan dari kehidupan masyarakat, justru harus diintegrasisan kedalam masyarakat. Sehingga dengan demikian, setiap narapidana berhak mendapatkan pembebasan bersyarat. Narapidana mempunyai hak untuk surat-menyurat, hak dikunjungi atau mengunjungi, mendapatkan remisi, cuti, serta lepas bersyarat. Pembebasan bersyarat merupakan sebuah metode pelepasan narapidana (offenders) dari Lapas sebelum masa

\footnotetext{
${ }^{6}$ Petrus Irwan Pandjaitan dan Wiwik Sri Widiarty, Pembaharuan pemikiran DR. Sahardjo Mengenai Pemasyarakatan Narapidana, Indhill Co, Jakarta, 2008, hlm. 23

${ }^{7}$ R. Achmad S. Soemadipradja dan Romli Atmasasmita, Sistem Pemasyarakatan Di Inodonesia, Binacipta, Bandung, 1979, hlm. 17

${ }^{8}$ E.Y. Kanter dan S. R. Sianturi, Asas-Asas Hukum Pidana di Indonesia dan Penerapannya, cet. 3, Storia Grafika, Jakarta, 2002, hlm. 473
} 
berakhirnya hukuman mereka. Para narapidana diskrining / disaring untuk penyesuaian mereka guna pelepasan yang didasari atas resiko yang mereka miliki terhadap masyarakat. Di Inggris pembebasan bersyarat dikenal dengan istilah parole yang artinya janji dan syarat-syarat kebebasan yang mempunyai unsur bimbingan ${ }^{9}$.

Pengertian pelepasan bersyarat tidak secara tersurat dituliskan dalam KUHP. Ketentuan pelepasan bersyarat dalam KUHP yang ditetapkan dengan K.B. No.33 tanggal 15 Oktober 1955 yang berlaku di Indonesia pada tanggal 1 Januari1918 (vide Stb. 1917-497 juncto 645) ${ }^{10}$, mengalami perubahan melalui Stb. 1926-251 juncto 486. ${ }^{11}$ Pada Pasal 15 lama ditentukan bahwa pelepasan bersyarat diterapkan kepada penjatuhan pidana penjara yang panjang.

Pelepasan bersyarat akan diberikan apabila tiga perempat dari pidananya telah dijalani dalam penjara, yang sekurangkurangnya harus tiga tahun. Sedangkan pada Pasal 15 KUHP yang diubah dengan Stb 1926-251 jo 486, yang merupakan KUHP yang berlaku hingga sekarang, pelepasan bersyarat dapat diberikan kepada terpidana yang telah menjalani 2/3 (dua per tiga) dari lamanya pidana penjara yang dijatuhkan kepadanya, yang sekurangkurangnya harus 9 (sembilan) bulan, dimana ketentuan ini juga berlaku pada saat istilah pembebasan bersyarat digunakan.

Selanjutnya, dalam peraturan perundang-undangan yang mengatur mengenai pelepasan bersyarat, yaitu KUHP dan Ordonansi Pelepasan Bersyarat (Voorwaardelijke Invrijheidsteeling) S. 1917-749, tidak terdapat ketentuan mengenai bimbingan dan pembinaan terhadap terpidana yang menjalani pembebasan bersyarat. Hal tersebut berbeda pada saat istilah pembebasan bersyarat digunakan, yakni terdapat pengaturan mengenai bimbingan dan pembinaan dalam ketentuan pembebasan bersyarat, yaitu dalam Undang-UndangNomor 12 Tahun 1995 tentang Pemasyarakatan, yang menyatakan bahwa terpidana yang menjalani pembebasan bersyarat wajib mengikuti bimbingan yang diberikan oleh Balai Pemasyarakatan (BAPAS).

Pelepasan bersyarat pada awalnya dikenal di dalam Wetboek Van Strafrecht (WvS) Belanda, kemudian dirubah dengan Stb. 1926 No. 251 jo 486 yang merupakan kelanjutan dari Stb. 1917 No. 749 yang saat ini dikenal sebagai Ordonnantie Op De Voorwaardelijke Invrjheids Stelling. $::^{12}$

Lamintang mengatakan bahwa pembebasan bersyarat dibagi menjadi dua golongan, yaitu

1. Pembebasan bersyarat dari kewajiban untuk menjalankan pidana penjara dalam suatu lembaga pemasyarakatan seperti yang diatur dalam Pasal 15 sampai Pasal 17 KUHP, lebih lanjut setelah diatur dalam ordonansi tanggal 27 Desember 1917, Stb nomor 749 yang juga dikenal sebagai ordonansi de voorwardelijjke invrijheidstelling atau peraturan mengenai Pembebasan bersyarat.

\footnotetext{
${ }^{9}$ Andi Hamzah, Sistem Pidana Dan Pemidanaan Indonesia Dari Retribusi ke Repormasi, PT. Pradiya Pramita, Jakarta, 1986, hlm. 35

${ }^{10}$ Bambang Poernomo, Pelaksanaan Pidana Penjara Dengan Sistem Pemasyarakatan, Liberty, 1985, Yogyakarta, hlm. 87

${ }^{11}$ E.Y. Kanter dan S. R. Sianturi, op. cit., hlm. 476.

${ }^{12}$ P.A.F. Lamintang, Hukum Penitensier Indonesia, Armico, 1984, Bandung, hlm. 247-248.
} 
2. Pembebasan bersyarat dari kewajiban untuk mendapatkan pendidikan dalam suatu lembaga pendidikan suatu Negara seperti yang dimaksud dalam Pasal 68 ayat (2) dan Pasal 69 ayat (1) dari ordonansi pada tanggal 21 Desember 1917, Stb nomor 741 yang juga dikenal sebagai dwangopveding regeling atau peraturan mengenai pendidikan paksa.

Pembebasan yang akan dijelaskan lebih lanjut adalah pembebasanbersyarat dari kewajiban untuk menjalankan pidana penjara sebagai manatelah diatur dalam Pasal 15 sampai dengan Pasal 16 KUHP.

Dalam praktek dibidang hukum khususnya hukum pidana sering dijumpai berbagai terjemahan yang berbeda-beda mengenai pembebasan bersyarat. Dalam bahasa Belanda digunakan istilah voorwardelijke invrijheidstelling yang jika diterjemahkan artinya Pembebasan Bersyarat. $^{13}$

BPHN menggartikannya dengan istilah pelepasan bersyarat tanpa menyadari bahwa istilah tersebut dapat menimbulkan salah penafsiran terutama bagi orang awam, karena istilah pelepasan ini tidak lazim digunakan dalam hukum pidana dan BPHN sendiri sering mengalami kesulitan dalam penggunaannya. ${ }^{14}$

Istilah pembebasan bersyarat akan Nampak lebih lazim digunakan dalam hukum pidana jika dalam Pasal 191 ayat (1) dan ayat (3), Pasal 192ayat (1), Pasal 183 ayat (2) huruf b KUHP dan lain-lain. ${ }^{15}$ Dalam KUHP kita tidak ada Pasal yang menyebutkan pengertian pembebasan bersyarat, KUHP hanya menyebutkan mengenai syarat-syarat bahwa seorang narapidana berhak mendapatkan pembebasan bersyarat.

Pengertian pembebasan bersyarat ini akan nampak lebih jelas jikakita melihat peraturan perundang-undangan diluar KUHP dan pendapat para pakar bidang ilmu hukum. Pembebasan bersyarat menurut ketentuan Pasal 1 huruf b Keputusan Menteri Kehakiman Nomor M.01PK.04.10 Tahun 1999 tentang Asimilasi, Pembebasan Bersyarat dan Cuti Menjelang Bebas adalah Pembebasan bersyarat dan cuti menjelang bebas adalah proses pembinaan narapidana di luar lembaga pemasyarakatan, berdasarkan ketentuan Pasal 15 dan 16 KUHP serta Pasal 14, Pasal22 dan Pasal 29 Undang-undang Nomor 12 Tahun 1995 tentang Pemasyarakatan.

Mengenai pengawasan terhadap narapidana yang sedang menjalankan pembebasan bersyarat dilakukan oleh Kejaksaan Negeri dan BAPAS. Pengawasan tersebut dimaksudkan untuk tetap memonitor segala perbuatan narapidana dalam menjalani cuti yang diberikan. Apabila nantinya dalam pelaksanaan bebas bersyarat terdapat narapidana ternyata hidup secara tidak teratur, bermalas-malasan berkerja, bergaul dengan residivis, mengulangi tindak pidana, menimbulkan keresahan dan melanggar ketentuan mengenai pelaksanaan pembebasan bersyarat maka pembebasan yang di berikan dicabut kembali.

Selain Pembebasan Bersyarat, ada juga program yang bernama Asimilasi. Asimilasi berasal dari bahas latin yaitu assimilare yang berarti "menjadi sama". ${ }^{16}$ Berdasarkan pengertian Asimilasi terkhusus di Lembaga Pemasyarakatan yang dimana setiap narapidana dapat bekerja

\footnotetext{
${ }^{13}$ Ibid, hlm. 250

${ }^{14}$ Ibid

${ }^{15}$ Ibid

${ }^{16}$ D. Hendrapuspito, Sosiologi Semantik. Kanisius, Yogyakarta, 1989, hlm. 233
} 
dan berbaur ke masyarakat di luar Lembaga Pemasyarakatan tetapi dalam pengawasan pegawai. Undang-undang no 12 Tahun 1999 tentang Pemasyarakatan memberikan penjelasan Asimilasi yang merupakan proses pembinaan yang dilakukan dengan cara membaur dalam masyarakat yang dalam pasal 14 huruf (j) berbunyi mendapatkan kesempatan berasimilasi termasuk cuti mengunjungi keluarga. Merupakan hak dari narapidana akan tetapi untuk memperoleh hak berupa Asimilasi narapidana harus memenuhi syarat tertentu terlebih dahulu yang tidak di atur dalam Undang-undang Pemasyarakatan berdasarkan pasal 14 ayat (2) yang berbunyi ketentuan mengenai syarat-syarat dan tata cara pelaskanaan hak-hak narapidana sebagaimana dimaksud ayat (1) diatur lebih lanjut dengan Peraturan Pemerintah.

Untuk mengetahui syarat dan tata cara Asimilasi berdasarkan Peraturan Pemerintah Nomor 32 Tahun 1999 Tentang Syarat dan Tata Cara Pelaksanaan Hak Warga Binaan Pemasyarakatan dalam Pasa 36 ayat (1) Narapidana dan Anak Didik Pemasyarakatan mendapatkan Asimilasi sebagaimana dimaksud dalam Pasal 36 dengan ketentuan:

1. Untuk Narapidana dan Anak Pidana setelah menjalani pembinaan 1/2 (satu per dua) masa pidana;

2. Untuk Anak Negara dan Anak Sipil setelah menjalani masa pendidikan di LAPAS Anak 6 (enam) bulan pertama;

3. Dapat mengikuti program pembinaan dengan baik;

4. Berkelakuan baik.

Pemberian Asimilasi kepada narapidana tidak langsung berikan begitu saja ada beberapa syarat yang harus di penuhi untuk mendapatkan program pembinaan Asimilasi. Tata Cara Pemberian Asimilasi bagi Warga binaan adalah: ${ }^{17}$

1. Pemberian Asimilasi dilaksanakan melalui sistem informasi pemasyarakatan.

2. Sistem informasi pemasyarakatan sebagaiamana dimaksud merupakan sistem informasi pemasyarakatan yang terintregrasi antara unit pelaksanaan teknis pemasyarakatan, Kantor Wilayah dengan Direktorat Jendral.

Dalam Pelaksanaan Terhadap Hak Klien Pemasyarakatan Untuk Memperoleh Bimbingan Di Balai Pemasyarakatan Klas I Padang, berdasarkan hasil penelitian penulis terdapat prinsipprinsip yang dapat dilaksanakan sebagai pedoman agar bimbingan dapat terlaksana dengan baik sesuai dengan perencanaan dan tujuan akhir dari proses pemasyarakatan.

1. Prinsip Dasar

Prinsip Dasar adalah pedoman arah atau pegangan sikap dan tingkah laku bagi Pembimbing Kemasyarakatan dalam memberikan pembimbingan terhadap klien. Adapun prinsip-prinsip dasar tersebut sebagai berikut:

a. Pengakuan bahwa setiap manusia mempunyai martabat, harga diri dan kehormatan yang harus dihargai dan dijunjung tinggi.

\footnotetext{
${ }^{17}$ Wawancara Penulis dengan Pembimbing Kemasyarakatan ahli Muda Bapas Klas I Padang, Bapak Ade Yadrul, S.H.MH.
} 
b. Pengakuan bahwa setiap manusia tidak sempurna. Artinya semua manusia memiliki keterbatasand an ia berhak untuk menentukan sendiri kekurangan dan cara untuk mengatasinya.

c. Pengakuan bahwa semua manusia mempunyai hak dan kesempatan yang sama, namun kesempatanan itu dibatasi oleh kemampuan masing-masing individu.

d. Pengakuan bahwa penghormatan pada diri sendiri, harga diri, penentuan nasib sendiri dan kesempatan yang berkaitan erat dengan pertanggung jawaban sosial terhadap diri sendiri, keluarga serta lingkungan.

2. Prinsip Praktik

Beberapa prinsip praktik yang diajukan oleh dari pakar pekerjaan sosial Menurut Henry S. Mass adalah sebagai berikut: ${ }^{18}$

a. Prinsip Penerimaan (The Principle of Acceptance)

Prinsip ini mengemukakan bahwa seorang Pembimbing Kemasyarakatan dalam menerima klien harus bebas nilai. Pembimbing Kemasyarakatantidak boleh "menghakimi" klien seakan-akan Pembimbing Kemasyarakatan yakin dan percaya bahwa klien adalah satusatunya pihak yang patut dipersalahkan atas apa yang telah diperbuatnya. Pembimbing Kemasyarakatan harus mampu membangun suasana yang akrab agar klien merasa nyaman dan dapat memberikan keterangan yang objektif, detil dan jujur sehingga Pembimbing Kemasyarakatan juga akan mendapatkan data yang valid dan akurat berdasarkan jawaban klien tersebut.

Sikap menerima sangat berlawanan dengan sikap menghakimi,oleh karena itu Pembimbing Kemasyarakatan perlu mempersiakan diri untuk tidak memberikan penilaian awal yang buruk. Pembimbing Kemasyarakatan harus mampu memahami klien apa adanya dengan membangun suasana yang akrab dengan klien sehingga terbangun kepercayaan dirinya terhadap Pembimbing Kemasyarakatan, sehingga yakin bahwa Pembimbing Kemasyarakatan dapatmembantu dirinya untuk dapat menyelesaikan masalah yang dihadapinya.

b. Prinsip Komunikasi (The Principle of Communication)

Prinsip komunikasi ini erat kaitannya dengan kemampuan Pembimbing Kemasyarakatan untuk menangkap informasi ataupun pesan yang dikemukakan oleh klien. Bentuk komunikasi yang diungkapkan Pembimbing Kemasyarakatan dapat berupa verbal maupun non verbal, seperti cara duduk klien, posisi ataupun letak duduk dalam suatu pertemuan dengan anggota keluarga yang lain, cara bicara, cara berpakaian, dan lain sebagainya.

Bila klien tidak dapat mengungkapkan apa yang dirasakannya, seorang Pembimbing Kemasyarakatan diharapkan dapat membantu untuk mengungkapkan apa yang ia rasakan. Hal lain yang perlu diperhatikan oleh Pembimbing Kemasyarakatan adalah menyadari ekspektasi (harapan) dari klien. Memberikan kesempatan kepada klien untuk mengungkan

\footnotetext{
${ }^{18}$ Modul Pembimbing Kemasyarakatan, Direktorat Jenderal Pemasyarakatan kementerian Hukum dan HAM RI, September 2021, Hlm 54-56
} 
perasaannya saat itu misalnya perasaan takut, marah, benci, sedih, gembira, dan lain sebagainya, sehingga komunikasi antara klien dan sistem klien dengan Pembimbing Kemasyarakatan dapat terjaga dan semakin berkembang.

c. Prinsip Individualisasi (The Principleof Individualization)

Prinsip individualisasi, pada intinya menganggap setiap individu berbeda satu dengan yang lainnya. Setiap individu adalah unik, sehingga pendekatan yang diutamakan adalah kasus per kasus dan bukan penggeneralisasian. Pembimbing Kemasyarakatan harus dapat menyesuaikan cara berkomunikasi dan memberikan bantuan dengan setiap kliennya, guna mendapatkan hasil yang optimal. Pembimbing Kemasyarakatan tidak boleh memasukkan kliennya ke dalam stereotype tertentu tanpa melakukan observasi yang mendalam karena dapat mengakibatkan hambatandalam hubungan antara Pembimbing Kemasyarakatan dengan klien.

d. Prinsip Partisipasi (The Principle of Participation)

Berdasarkan prinsip ini, seorang Pembimbing Kemasyarakatan harus dapat mengajak kliennya untuk berperan aktif dalam upaya mengatasi permasalahan yang dihadapinya . Dengan demikian klien memiliki tanggungjawab terhadap keberhasilan proses pemberian bantuan tersebut. Tanpa adanya kerja sama dan peran serta dari klien maka upaya pemberian bantuan sulit untuk mendapatkan hasil yang optimal. Apabila klien kurang kooperatif, maka Pembimbing Kemasyarakatan perlu membangun sudut pandang yang tepat bagi klien, sehingga klien mengetahui manfaat dari proses penyelesaian masalah yang dihadapi.

e. Prinsip Kerahasiaan (The Principle of Confidentiality)

Dalam menjalankan proses pembimbingan serta pendampingan, Pembimbing Kemasyarakatan harus senantiasa menjaga kerahasiaan klien. Rahasia klien harus dilindungi dan dihormati, kecuali atas persetujuan klien. Hal ini sangat dibutuhkan agar memudahkan Pembimbing Kemasyarakatan dalam memperoleh informasi yang utuh, untuk itu Pembimbing Kemasyarakatan harus mampumembangun kepercayaan klien terhadap dirinya.

f. Prinsip Kesadaran diri (The Principle of Caseworker self-Awarness)

Pembimbing Kemasyarakatan merupakan manusia biasa yang memiliki motivasi pribadi yangkompleks, oleh karena itu harus mampu memisahkan urusan pribadi denganpekerjaan secara professional. Hal tersebut untuk menghindari terjadinya kesalahan dalam membuat penelitian kemasyarakatan dan tidak terhanyut dalam perasaan ataupun permasalahan yang dihadapi oleh kliennya.

Proses pembimbingan klien pemasyarakatan yang dilakukan pada Balai Pemasyarakatan sebagaimana hasil penelitian pada BAB III adalah dengan mekanisme langkah Pembimbingan Tahap Awal, Pembimbingan Tahap lanjutan dan Pembimbingan Tahap Akhir dengan pelaksanaan di lakukan sebagai berikut: ${ }^{19}$

1. Pemanggilan klien ke Balai Pemasyarakatan

\footnotetext{
${ }^{19}$ Wawancara Penulis dengan Pembimbing Kemasyarakatan ahli Muda Bapas Klas I Padang, Bapak Ade Yadrul, S.H. MH.
} 
Ini merupakan tahap paling awal sebelum bimbingan dilakukan oleh Pembimbing Kemasyarakatan. Pada tahap ini dilakukan penerimaan dan pencatatan atas data klien serta dokumen pendukung yang terkait diri klien. Pencatatan ini dilakukan oleh bagian Registrasi. Proses penerimaan dan pencatatan antara lain:

a. Klien diterima oleh petugas piket di Balai Pemasyarakatan kemudian diperiksa identitas klien beserta kelengkapan dokumen yang dimiliki klien.

b. Data klien akan dicatat dalam buku piket yang dipergunakan untuk mencatat dan tertip administrasi.

c. Setelah mencatat segala peristiwa, petugas piket akan mengantar klien kepada petugas pendaftar.

d. Petugas pendaftar akan kembali mengoreksi keaslian identitas klien beserta kelengkapan surat-suratnya.

e. Setelah dibuatkan berita acaranya kemudian didaftarkan ke dalam buku yang sesuai dengan status klien.

f. Setelah didaftarkan dalam buku yang sesuai dengan status klien, maka petugas pendaftar akan memberikan kartu bimbingan, serta klien akan diminta foto dan diambil sidik jarinya.

g. Selanjutnya klien akan diantarkan kepada Pembimbing Kemasyarakatan yang akan membimbing klien selama masa bimbingan.

2. Pengenalan kepada Petugas Kemasyarakatan (PK)

Pada tahapan ini, klien akan diperkenalkan kepada petuga PK, akan membimbing klien selama pembebasan bersyarat. Klien tersebut akan diberikan penjelasan mengenai:

a. Arti masa percobaan yang akan dijalani;

b. Maksud dan tujuan pembinaan dan pembimbingan yang dilakukan oleh Balai Pemasyarakatan;

c. Hal-hal yang boleh dilakukan dan tidak boleh dilakukan selama menjalani masa bimbingan;

d. Hal-hal lain sepanjang masih berhubungan dengan pembinaan dan pembimbingan klien.

3. Pemberitahuan dari Balai Pemasyarakatan ke pihak terkait sehubungan dengan adanya bimbingan yang dilakukan. Pemberitahuan disampaikan kepada:

a. Perangkat desa setempat (Ketua RT/TW, Lurah/Nagari dan Camat setempat);

b. Kejaksaan yang mengawasi;

c. Kepolisian setempat;

d. Lembaga Pemasyarakatan yang melepas klien dan pengadilan yang mengadili klien;

e. Kepala Daerah setempat.

4. Petugas Balai Pemasyarakatan akan mengunjungi rumah klien. Selama mengunjungi rumah klien, petugas bertugas melakukan:

a. Mengisi kartu konseling untuk klien;

b. Melakukan penelitian kemasyarakatan tersebut;

c. Membuat catatan untuk bahan laporan bulanan. 
5. Berdasarkan hasil kunjungan rumah yang pertama, akan dibuatkan rencana pembinaan selama bimbingan.

6. Kunjungan rumah kedua merupakan pembinaan yang telah ditentukan serta membuat bahan untuk laporan bulanan.

7. Kunjungan rumah yang ketiga akan dilakukan evaluasi terhadap pembinaan yang telah berjalan dan untuk selanjutnya dapat diberikan pembinaan baru serta membuat catatan untuk bahan laporan bulanan.

8. Pembuatan laporan triwulan mengenai perkembangan klien.

9. Pelaksanaan pembinaan dan evaluasi sampai berakhir masa bimbingan klien.

10. Evaluasi akhir berupa penilaian seluruh pembinaan yang telah dilakukan oleh petugas PK.

11. Pembuatan surat keterangan yang menyatakan berakhirnya masa bimbingan klien.

12. Laporan BAPAS mengenai berakhirnya bimbingan klien

Dalam hal melaksanakan bimbingan terhadap klien, Balai Pemasyarakatan Kelas I Padang melalui Pembimbing Kemasyarakatan juga melaksanakan dengan 2 (dua) cara yaitu:

1. Dengan cara datang langsung ketempat tinggal klien (Home Visit)

Kunjugan tersebut diprioritaskan terhadap klien yang sudah lama tidak datang ke Balai Pemasyarakatan untuk melakukan kewajibannya karena jaraknya yang terlampau jauh. Dengan kata lain para petugas Balai Pemasyarakatan Klas I Padang yang bertugas sebagai Pembimbing Kemasyarakatan turun langsung kelapangan untuk mengunjungi klien ditempat tinggalnya. Dalam melakukan bimbingan, disini Balai Pemasyarakatan menggunakan teknik wawancara dimana petugas Pembimbing Kemasyarakatan melakukan Tanya-jawab secara langsung kepada para klien.

Berdasarkan data rekapitulasi sebagaimana BAB III, dapat ditarik kesimpulan bahwa cara datang langsung ketempat tinggal klien (Home Visit) lebih dominan terlaksana.

2. Dengan cara klien datang langsung ke Balai Pemasyarakatan Klas I Padang

Disini klien datang secara langsung untuk melapor dan absen ke Balai Pemasyarakatan Klas I Padang sesuai dengan jadwal yang sudah ditentukan sebelumnya dengan Pembimbing Kemasyarakatan. Dalam tiap harinya penulis melihat ada sekitar 6-10 klien yang datang untuk melapor dan absen. Hal tersebut menunjukan bahwa selama menjalani pembebasan bersyarat, klien mengerti akan kewajiban yang harus dipenuhi setiap bulannya. Ketika klien datang, Petugas Kemasyarakatan akan menyatakan keadaan, perkembangan klien sendiri tentang bagaimana sikap masyarakat terhadap klien setelah keluar dari Lembaga Pemasyarakatan. Dalam hal ini Balai Pemasyarakatan Klas I Padang menggunakan teknik wawancara.

Bentuk bimbingan yang diberikan Balai Pemasyarakatan Klas I Padang terhadap kliennya selama masa pembimbingan adalah:

1. Perorangan

Bimbingan ini diberikan kepada setiap klien yang datang ke B Balai Pemasyarakatan Klas I Padang ketika sedang menjalankan kewajibannya berupa melapor dan absen setiap bulannya. Bimbingan ini juga diberikan kepada klien yang jarang sekali datang ke Balai Pemasyarakatan karena jarak yang tempuh jauh. 
2. Perkelompok

Dalam bentuk bimbingan ini, Balai Pemasyarakatan Klas I Padang membentuk sebuah kelompok berdasarkan tempat tinggal klien, hal tersebut dilakukan dengan tujuan agar lebih mudah memberikan bimbingan.

Bimbingan tersebut diatas dilaksanakan dengan metode dan teknik sebagai berikut: ${ }^{20}$

1. Teknik Wawancara/Interview.

Tehnik ini terbagi dalam dua bagian :

a. Tehnik wawancara secara bebas. Dalam wawancara ini PK tidak boleh langsung bertanya dalam hal-hal pokok tentang masalah yang dihadapi klien. Terlebih dahulu PK mendapatkan kepercayaan klien, ditanyakan hal-hal keadaannya sehari-hari, kesehatan dan sebagainya dan dapat dilakukan secara terbuka dimana saja. Bagi klien yang ada di Lapas lebih mudah sehingga dapat dilakukan beberapa kali wawancara ini dapat dilakukan secara bertahap.

b. Wawancara secara mendalam apabila telah mendapat kepercayaan dengan mudah dilanjutkan secara mendalam mengenai segala permasalahan yang akan dituangkan dalam laporan nanti. Wawancara ini dapat dilakukan dalam rangka tertutup, atau di ruangan konseling, dengan keterampilan khusus pasti dapat diperoleh keterangan yang akurat karena kesabaran dan taktik yang cerdik.

2. Cara memanggil untuk lapor diri.

Pemanggilan ini dilakukan dalam rangka lapor diri untuk bimbingan klien. Setelah PK mendapat pemberitahuan dari Jaksa disertai vonis atau surat ketetapan yang telah dieksekusi melaluai kepala Balai Pemasyarakatan, PK memanggil klien untuk datang ke Balai Pemasyarakatan, baik untuk administrasi maupun bimbingan. Pelaksanaan lapor diri ini dapat dilakukan secara perorangan maupun kelompok dengan melihat kondisi klien yang bersangkutan. Dalam kegiatan ini PK harus melakukan kegiatan kreatif dengan macam-macam cara sebagai PK yang professional. Hanya dengan nasehat-nasehat saja bimbingan klien tidak akan berhasil. Saat lapor diri inilah dapat dilakukan berbagai kegiatan seperti tuntunan kerja, bimbingan rohani secara perorangan maupun permainan/olah raga, kesenian, keperpustakaan dan sebagainya. Sehingga dengan kebersamaan ini keakraban dan keharmonisan akan mendukung keberhasilan bimbingan terpadu.

3. Teknik Kunjungan Rumah (Home Visit)

Kunjungan rumah atau Home Visit oleh PK untuk melengkapi tehnik tehnik lain yaitu :

a. Mencari data dalam rangka pembuatan litmas baik untuk hakim maupun atas permintaan Kalapas ataupun Instansi lain.

b. Dalam rangka bimbingan klien.

Untuk memerlukan data yang diperlukan berhubungan langsung denganklien, orang tua atau keluarga dan masyarkat lingkungannya, sehingga dapat diperoleh data yang lengkap dan akurat. Dalam menjalankan tugas tersebut PK dilengkapi surat tugas Kepala Bapas yang diatur dalam tata usaha pemasyarakatan bidang khusus Bapas. Dengan melakukan kunjungan rumah

${ }^{20}$ Hasil wawancara Penulis dengan Kepala Bapas Klas I Padang, Bapak Karto Raharjo, Bc.IP., S.H.,M.H 
PK akan mendapat gambaran keadaan klien, keluarganya, pendidikan, keadaan social ekonomi keluarga dan masyarakatnya, yang dapat mempengaruhi pertumbuhan hidup klien yang bersangkutan. Selanjutnya dapat melakukan analisa apa yang perlu dilakukan guna perbaikan yang harus dilakukan klien maupun keluarga.

4. Teknik dengan melakukan Quistioner atau daftar pertanyaan.

Tehnik ini juga dapat digunakan untuk diisi oleh klien atau keluarganya, akan tetapi hasilnya kadang-kadang kurang dapat dipercaya dalam mengisi pertanyaan-pertanyaan dalam daftar pertanyaan tersebut.

5. Teknik dengan memakai dokumentasi

Dengan memakai tehnik dokumentasi dapat diperoleh catatan yang berkaitan dengan masalah klien yaitu dengan melihat surat-surat vonis dan ketetapan klien yang bersangkutan, surat-surat resmi lainnya dan buku agenda klien yang bersangkutan dengan buku agenda atau buku harian dapat diungkap permasalahan yang menyangkut diri klien.

6. Teknik Komunikasi

PK dapat melakukan komunikasi dengan klien melalui surat menyurat dan melalui telepon, jika tidak memiliki telepon dapat menggunakan telepon umum. Bahkan saat ini PK atau klien dapat menggunakan telepon seluler. Hubungan seperti ini bermanfaat bagi PK dalam rangka bimbingan klien.

7. Observasi

Observasi secara langsung maupun secara patisipatif yaitu dengan observasi timbal balik, tidak hanya keadaan klien yang diobservasi tetapi juga berbagai hal yang berkaitan dengan kliennya.

Faktor pendukung dalam pencapaian tujuan pemberian hak klien pemasyarakatan dalam memperoleh pembimbingan secara maksimal menurut analisa penulis dapat diupayakan dalam beberapa hal antara lain:

1. Sumber daya manusia, organisasi, keluarga dan masyarakat

Untuk mencapai tujuan dari bimbingan terhadap klien pemasyarakatan memang sangat membutuhkan sumber daya manusia (SDM) yang berpotensi dan mencukupi. Para Pembimbing Kemasyarakatan (PK) haruslah bekerja sungguh-sungguh dan menentukan langkah bimbingan terhadap kliennya. Selain itu pemilihan bimbingan dengan mitra juga jadi faktor pendukung. Keluarga dan masyarakat yang akan berinteraksi dengan klien juga harus selalu memberi dukungan kepada klien untuk suksesnya program pembebasan Bersyarat dan bimbingat klien kedepan.

2. Sumber daya institusi

Kerjasama Balai Pemasyarakatan Klas I Padang untuk proses bimbingan klien dengan institusi (Pemerintah, Swasta, Organisasi keagamaan dan badan-badan sosial) haruslah memiliki kwalitas yang baik dan berkwalitas agar program yang diberikan Balai Pemasyarakatan berjalan sesuai rencana dan target yang telah ditentukan guna suksesnya pembinaan klien dan kembali ketengah-tengah masyarakat dan keluarga, sehingga hak dari klien pemasyarakatan terpenuhi.

3. Sumber daya alam 
Klien setelah mendapatkan bimbingan dari Balai Pemasyarakat-an hendaklah bisa memanfaatkan sumber daya alam yang dimiliki lingkungan sekitar agar bisa kembali menjadi warga yang baik dan diterima keluarga dan masyarakat.

4. Adat istiadat dan dinamika sosial masyarakat

Adat istiadat dan dinamika sosial masyarakat sangat berpengaruh dalam program bimbingan klien, karena semuanya itu saling berhubungtan. Klien akan diajarkan bagaimana kembali ke masyarakat dengan baik dan tidak mengulangi perilaku melanggar hukum lagi

Balai Pemasyarakatan sendiri mempunyai tugas dan fungsi menyelenggarakan sebagian dari tugas pokok Direktoral Jendral Pemasyarakatan dalam menyelenggarakan pembimbingan klien pemasyarakatan di daerah. Bentuk dari bimbingan yang diberikan bermacam-macam, mulai dari pemberian pembinaan tentang agama, keterampilan, sampai pada pembinaan kepribadian. Bimbingan ini diberikan dengan tujuan agar klien dapat hidup dengan baik didalam masyarakat sebagai warga negara serta bertanggung jawab, untuk memberikan motivasi, agar dapat memperbaiki diri sendiri, tidak mengulangi tindak kejahatan.

Prosedur dan mekanisme pengawasan klien melalui wajib lapor adalah sebagai berikut:

1. Klien datang dan mengisi buku piket di petugas piket

2. Klien menemui Petugas PK

3. Klien melaksanakan kegiatan bimbingan konseling dengan PK

4. PK membuat laporan

Prosedur dan mekanisme pengawasan klien melalui kunjungan rumah (home Visit) adalah sebagai berikut:

1. Petugas PK memeriksa dan menyiapkan berkas klien

2. Petugas PK dengan surat tugas dari Kabapas melakukan kunjungan ke rumah klien/ penjamin / pemerintah setempat

3. PK memberikan bimbingan konseling kepada klien dirumahnya

4. PK menemui pemerintah setempat untuk mengetahui perkembangan perilaku klien di masyarakat

5. PK menemui perwakilan warga setempat unutk mengetahui perilaku dan perkembangan klien sehari-hari.

Sesuai dengan Permenkumham RI No.M.01.PK.04-10 tahun 2007 tentang Syarat dan Tatatcara Pelaksanaan Asimilasi, Pembebasan Bersyarat, Cuti Menjelang Bebas dan Cuti Bersyarat. Klien yang kembali melakukan tindak pidana selama masa bimbingan akan langsung dicabut hak pembebasan bersyaratnya.

\section{Kendala Yang Ditemukan Dalam Pelaksanaan Perlindungan Hak Klien Pemasyarakatan} Untuk Memperoleh Bimbingan Di Balai Pemasyarakatan Klas I Padang

Kamus Besar Bahasa Indonesia mendefinisikan pengertian kendala adalah halangan rintangan dengan keadaan yang membatasi, menghalangi atau mencegah pencapaian sasaran. Dalam hal ini kendala yang akan dikaji adalah kendala yang ditemukan dalam pelaksanaan perlindungan hak klien pemasyarakatan dalam memperoleh pembimbingan. Kendala dalam 
pelaksanaan perlindungan hak klien pemasyarakatan dalam memperoleh pembimbingan ini adalah beberapa hambatan yang menghambat jalannya proses dimaksud pada Balai Pemasyarakatan Kelas I Padang.

Tidak semua Pembimbingan Klien Kemasyarakatan yang dilakukan Pembimbing Kemasyarakatan (PK) pada Balai Pemasyarakatan Kelas I Padang berjalan dengan lancar. Dalam melakukan pembimbingan, ada beberapa kendala yang ditemui oleh Pembimbing Kemasyarakatan. Hal-hal tersebut diungkapkan oleh beberapa Petugas Pemasyarakatan pada Balai Pemasyarakatan Klas I Padang. Kendala yang dihadapi tersebut berdasarkan hasil penelitian penulis adalah:

1. Kendala dari segi Sumber Daya Manusia (SDM)

Berdasarkan data dari Balai Pemasyarakatan Klas I Padang, jumlah klien yang dalam masa pembimbingan adalah 1.536 klien (data tahun 2020), sedangkan jumlah pegawai Balai Pemasyarakatan Klas I Padang sebanyak 70 pegawai $^{21}$. Perbandingan jumlah pegawai dengan klien ini sangat besar berpengaruh terhadap proses pembimbingan. Hal ini menyebabkan proses pembimbingan terlaksana kurang optimal. Dari total jumlah pegawai pun tidak semuanya yang merupakan Pembimbing Kemasyarakatan. Jumlah Pembimbing Kemasyarakatan (PK) pada Balai Pemasyarakatan Klas I Padang adalah 45 orang. Petugas Pemasyarakatan hanya bisa bekerja sesuai kemampuan demi memberi kontribusi maksimal bagi Institusi secara umum dan bagi Klien Pemasyarakatan secara khusus. Dan dengan keterbatasaan tenaga Pembimbing Kemasyarakatan ini lah membuat tidak semua klien dapat dikunjungi secara langsung. Bagusnya sebuah peraturan terkait pemasyarakatan ini kalaulah tidak didukung dengan SDM dari pelaksana aturan tersebut dalam hal ini BAPAS, pastilah tidak akan berjalan dengan baik dan menciptakan hasil yang diharapkan sebagaimana cita-cita dan harapan dari substansi hukumnya.

2. Kendala dari Kesadaran Diri Klien Pemasyarakatan

Klien Pemasyarakatan banyak yang belum tau dan memahami manfaat serta tujuan diadakan program bimbingan seperti yang direncanakan dan disusun oleh Balai Pemasyarakatan. Klien banyak yang enggan mengikuti pelatihan/kursus yang diadakan Balai Pemasyarakatan. Ini banyak diakibatkan perasaan terkekang klien dan merasa masih dipidana seperti pada masa pembinaan di Lembaga Pemasyarakatan. Selain itu klien juga banyak yang sudah bekerja dan mencari nafkah untuk kehidupan sehari-hari. Klo klien tersebut mengikuti program dari Balai Pemasyarakatan, tentunya tidak akan dapat menghasilkan untuk kebutuhan hidup sehari hari. Ini juga merupakan pertimbangan serius dan mendasar Klien dalam mengikuti Program Bimbingan.

Pada saat Pembimbing Kemasyarakatan mengunjungi klien kadangkala para Pembimbing Kemasyarakatan tidak bertemu dengan kliennya yang mengakibatkan Pembimbing Kemasyarakatan tidak bisa melakukan bimbingan, tetapi petugas masih bisa bertemu dengan aparat desa dan keluarga untuk menanyakan keadan dari klien. Yang paling terkendala adalah alamat klien yang berpindah-pindah karena menyewa rumah tinggal.

\footnotetext{
${ }^{21}$ Wawancara Penulis dengan Kepala SubBagian Tata Usaha, Ibu Lily Reni, S.Sos
} 
3. Kendala dari Sarana dan prasarana penunjang tugas dan fungsi Balai Pemasyarakatan Klas I Padang

Dalam proses bimbingan terhadap klien pemasyarakatan, Balai Pemasyarakatan Klas I Padang sangat minim dengan sarana dan prasarana. Alat transportasi yang digunakan untuk proses pembimbingan dan operasional kantor hanya 1 (satu) unit mobil dan beberapa kendaraan roda dua yang digunakan sebagian Pembimbing Kemasyarakatan. Mobi itupun sering digunakan Kepala Balai Pemasyarakatan untuk urusan kedinasan lainnya. Selain itu, sarana untuk bimbingan juga sangat minim. Untuk bimbingan lain banyak bekerja sama dengan pihak ke-3 (pihak luar).

4. Kendala Alokasi Anggaran Balai Pemasyarakatan Klas I Padang

Balai Pemasyarakatan Klas I Padangdalam tugas dan fungsi untuk pembimbingan klien pemasyarakatan banyak terkendala masalah anggaran dari pusat. Anggaran yang diperoleh tiap tahun kurang mencukupi untuk pelaksanaan bimbinghan dan operasional kantor. Hal ini mengakibatkan kurang optimalnya program bimbingan keterampilan yang diberikan kepada klien pemasyarakatan. Anggaran yang diperoleh Balai Pemasyarakatandari pemerintah untuk melakukan pembimbingan ini tidak seimbang dengan apa yang diperlukan. Dengan luasnya wilayah kerja Balai Pemasyarakatan Kelas I Padang membuat anggaran yang diberikan tidak cukup atau tidak sesuai dengan apa yang diperlukan Balai Pemasyarakatan Kelas I Padang. ${ }^{22}$

5. Kendala Komunikasi

Dalam berkomunikasi, Balai Pemasyarakatan dengan klien pemasyarakatan memang agak banyak berkendala. Selama ini komunikasi Pembimbing dengan klien hanya menggunakan telepon seluler dan surat melalui Kantor Pos. Kalau dihubungi lewat telepon seluler, kebanyakan klien enggan menggangkat atau no telepon nya sering diganti sehingga kontak antara pembimbing dengan klien terputus. Pengiriman surat panggilan melalui surat pun banyak juga yang tidak di respon.Lokasi tempat tinggal klien yang jauh dan terpencil juga membuat sulit untuk dijangkau dengan kendaraan umum serta alamat klien yang dicatat oleh Balai Pemasyarakatan Kelas I padang tidak jelas dan tidak sama denga alamat yang sebenarnya. $^{23}$

6. Kendala dalam hal stigma sosial

Masyarakat telah memfonis bahwa mantan narapidana / klien itu adalah penjahat. Stigma sosial sering menyebabkan pengucilan. Sangat susah memberikan edukasi kepada masyarakat terkait status sosial klien ini. Perlu adanya sosialisasi mengenai pemasyarakatan sehingga masyarakat diharapkan bisa menerima kembali klien ke dalam masyarakat dan bekerjasama dalam proses Integrasi klien ini ditengah-tengah masyarakat. Menanamkan budaya hukum kepada masyarakat untuk bekerjasama dengan pemerintah dalam proses Integrasi sosial Klien ini sangatlah menjadi kendala serius selama ini yang dihadapi Pembimbing Kemasyarakatan BAPAS.

\footnotetext{
${ }^{22}$ Ibid

${ }^{23}$ Hasil wawancara Penulis dengan Kasubsie Bimbingan Kemasyarakatan Bapas Klas I Padang, Bapak Yangki Yama Permindo, S.H
} 
Upaya yang dapat ditempuh untuk mengoptimalkan pelaksanaan terhadap hak klien pemasyarakatan untuk memperoleh bimbingan di Balai Pemasyarakatan Klas I Padang

1. Upaya dari Kendala segi Sumber Daya Manusia (SDM)

Upaya yang dilakukan dengan melalui peningkatan Kompetensi Pegawai Bapas. Peningkatan Kompetensi sumber daya manusia (SDM) dengan cara mengadakan bimbingan teknis, diklat dan sejenisnya terhadap petugas pemasyarakatan agar dalam melakukan pekerjaan sehari-hari lebih berkualitas dan terampil dalam menangani klien pemasyarakatan tersebut. Dengan Balai Pemasyarakatan yang merupakan bagian dari struktur hukum dengan didukung substansi hukum yakni Undang-undang Pemasyarakatan dan aturan pelaksananya yang baik juga dengan klien pemasyarakatan yang dibimbing dapat memiliki kesadaran hukum dan budaya hukum tentunya akan terciptanya supremasi hukum.

Selain itu perlu juga penambahan personil petugas pemasyarakatan dilakukan mengingat wilayah kerja Bapas Klas I Padang cukup luas. Dengan jumlah pegawai Balai Pemasyarakatan Kelas I Padang yang sedikit, maka Balai Pemasyarakatan Kelas I Padang berusaha semaksimal mungkin agar setiap klien mempunyai Pembimbing Kemasyarakatan. Hasilnya setiap Pembimbing Kemasyarakatan memegang lebih dari sepuluh klien. Selain

2. Upaya dari Kendala Kesadaran Diri Klien Pemasyarakatan

Upaya dengan meningkatkan kesadaran hukum klien melalui bimbingan yang diberikan secara maksimal. Dengan bimbingan yang dilaksanakan sesuai dengan pedoman dan aturan yang berlaku, didukung dengan SDM Petugas yang baik tentunya akan bisa menghasilkan hasil yang diharapkan.

3. Upaya dari Kendala Sarana dan prasarana penunjang tugas dan fungsi Balai Pemasyarakatan Klas I Padang

Mengusulkan sarana dan prasarana penunjang tugas kepada pimpinan pusat (Kementerian). Mengusulkan kendaraan dinas kepada Direktorat Jenderal Pemasyarakatan Kementerian Hukum dan HAM agar dalam kegiatan pembinaan ke luar kota padang bisa lebih efektif. Dengan fasilitas yang tidak memadai Balai Pemasyarakatan Kelas I Padang tetap mencari cara agar para klien yang sudah lama tidak datang ke Balai Pemasyarakatan Kelas I Padang untuk melapor diri atau absen, dapat dikunjungi oleh Pembimbing Kemasyarakatan, yaitu dengan naik trasportasi kendaraan umum dan pribadi.

4. Upaya dari Kendala Alokasi Anggaran Balai Pemasyarakatan Klas I Padang

Upaya dengan mengusulkan anggaran dalam perencanaan setiap tahunnya ke pimpinan pusat (Kementerian). Mengusulkan anggaran yang lebih besar dalam DIPA tahun berikutnya agar anggaran yang diperoleh cukup untuk kegiatan operasional sehari-hari. Dengan anggaran yang sedikit Balai Pemasyarakatan Kelas I Padang berusaha semaksimal mungkin agar anggaran atau dana yang ada cukup untuk melakukan bimbingan bagi para klien sehingga semua program pembimbingan yang ada dapat berjalan sesuai dengan yang diharapkan.

Melakukan kerja sama dengan pihak ke tiga dalam hal pembinaan narapidana yang menjalani pembebasan bersyarat (PB), seperti pendidikan keterampilan dan penyuluhan serta bimbingan kerohanian. Peran pekerja-pekerja sosial sukarela dapat juga diberdayakan. Jika 
ditinjau dari pelaksanaan pembinaan di luar lembaga, para petugas dapat menggunakan fasilitas yang ada di masyarakat. Pembinaan di luar lembaga mempunyai keuntungan karena pembinaan dapat dilakukan dengan menggunakan fasilitas yang ada di masyarakat untuk mengadakan rehabilitasi. Fasilitas ini dapat berupa bantuan pembinaan dari masyarakat setempat, jasa-jasa pengadaan lapangan pekerjaan pemerintah ataupun swasta dan sebagainya. Selain itu, membina kerjasama dengan instansi pemerintahan juga bisa dilakukan dengan menyesuaikan program kerja yang ada.

5. Upaya dari Kendala Komunikasi

Upaya dengan membina komunikasi denga stakeholder dan aparat setempat. Jika dalam melakukan kunjungan klien yang akan ditemui sedang tidak ada ditempat Balai Pemasyarakatan Kelas I Padang tetap mencari informasi klien pada keluarga dan aparat desa tentang keadaan serta tingkah laku klien saat berada didalam lingkungan masyarakat. Komunikasi juga bisa dibangun dengan aparat daerah setempat seperti Babinsa (TNI) dan Bhabinkamtibmas (Polri). Sinergi dengan aparat ini sangat membantu karena aparat ini bersentuhan langsung dengan kondisi dan dinamika sosial maysarakat sampai ditingkat paling bawah yakni RT/RW.

6. Upaya dari Kendala dalam hal Stigma Sosial

Upaya dengan bekerjasama dengan Penyuluh Hukum yang ada di Kantor Wilayah dalam mengedukasi Masyarakat. Melaksanakan penyuluhan hukum kepada masyarakat terkait stigma negatif terhadap klien Balai Pemasyarakatan ini agar masyarakat bisa menerima kembali klien dan bekerjasama dalam proses Integrasi klien ini ditengah-tengah masyarakat. Dengan struktur dari lembaga negara dalam hal ini BAPAS Klas I Padang sudah dilakukan secara baik dalam melaksanakan tugas dan fungsinya, didukung dengan regulasi yang sesuai dengan keadaan sosial masyarakat dan didukung dengan tingginya tingkat kesadaran hukum dan masyarakat yang berbudaya hukum, akan menghasilkan suatu proses yang sesuai dengan harapan mengembalikan manusia yang pernah tersesat dan melakukan pelanggaran hukum akan kembali kepada masyarakat dengan penuh kesadaran.

\section{KESIMPULAN}

Pelaksanaan Hak Klien Pemasyarakatan Untuk Memperoleh Bimbingan Di Balai Pemasyarakatan Klas I Padang adalah melalui prinsip dasar dan prinsip praktik melalui dua cara yakni datang langsung ketempat tinggal klien (Home Visit) dan dengan cara klien datang langsung ke Balai Pemasyarakatan Klas I Padang baik secara perorangan maupun perkelompok. Dari dua cara tersebut yang dominan dilakukan adalah dengan Home Visit. Bimbingan tersebut diatas dilaksanakan dengan metode dan teknik wawancara/interview, Cara memanggil untuk lapor diri, teknik kunjungan rumah (Home Visit), teknik dengan melakukan Quistioner atau daftar pertanyaan, teknik dengan memakai dokumentasi, teknik komunikasi dan observasi. Faktor pendukung dalam pencapaiannya adalah dengan mengupayakan peningkatan sumber daya manusia, organisasi, keluarga dan masyarakat, peningkatan sumber daya institusi, sumber daya alam serta adat istiadat dan dinamika sosial masyarakat. Kendala Yang Ditemukan Dalam 
Pelaksanaan Hak Klien Pemasyarakatan Untuk Memperoleh Pembimbingan Di Balai Pemasyarakatan Klas I Padang adalah kendala Internal, meliputi kendala dari segi Sumber Daya Manusia (SDM), sarana dan prasarana penunjang tugas dan fungsi Balai Pemasyarakatan Klas I Padang, alokasi anggaran Balai Pemasyarakatan Klas I Padang dan kendala Eksternal, yang meliputi kesadaran diri klien Pemasyarakatan, komunikasi serta stigma sosial. Upaya yang dilakukan untuk mengoptimalkan pelaksanaan hak klien pemasyarakatan untuk memperoleh bimbingan di Balai Pemasyarakatan Klas I Padang adalah dengan cara peningkatan kompetensi sumber daya manusia (SDM) melalui bimbingan teknis, diklat dan sejenisnya, meningkatkan kesadaran hukum klien melalui bimbingan yang diberikan secara maksimal, mengusulkan kendaraan operasional dan sarana penunjang lainnya, mengusulkan anggaran lebih besar, melakukan kerjasama dengan pihak terkait, mencari informasi klien yang tidak ditemukan kepada keluarga terdekat dan perangkat Kelurahan/Nagari serta melaksanakan penyuluhan hukum bekerjasama dengan Penyuluh Hukum Kanwil Kemenkumham Sumbar terkait stigma masyarakat dan pemahaman tentang pembimbingan klien.

\section{DAFTAR PUSTAKA}

Andi Hamzah, Sistem Pidana Dan Pemidanaan Indonesia Dari Retribusi ke Repormasi, PT. Pradiya Pramita, Jakarta, 1986

Bambang Poernomo, Pelaksanaan Pidana Penjara Dengan Sistem Pemasyarakatan, Liberty, Yogyakarta, 1985

D. Hendrapuspito, Sosiologi Semantik. Kanisius, Yogyakarta, 1989

Dede Erni Kartikawati, Dasar-Dasar Pembimbingan, Modul Latihan Dasar Calon Pembimbing Kemasyarakatan Pertama, Badan Pengembangan Sumber daya ManusiaKementerian Hukum Dan HAM Republik Indonesia Tahun 2016

E.Y. Kanter dan S. R. Sianturi, Asas-Asas Hukum Pidana di Indonesia dan Penerapannya, cet. 3, Storia Grafika, Jakarta, 2002

Maidin Gultom, Perlindungan Hukum Terhadap Anak dan Perempuan, PT Refika Aditama, Bandung, 2012

P.A.F. Lamintang, Hukum Penitensier Indonesia, Bandung: Armico, 1984

Petrus Irwan Pandjaitan dan Wiwik Sri Widiarty, Pembaharuan pemikiran Sahardjo Mengenai Pemasyarakatan Narapidana, Indhill Co, Jakarta, 2008

R. Achmad S. Soemadipradja dan Romli Atmasasmita, Sistem Pemasyarakatan Di Inodonesia, Binacipta, Bandung, 1979

Undang-undang Dasar Negara Republik Indonesia Tahun 1945

Undang-undang Nomor 12 Tahun 1995 tentang Pemasyarakatan

Undang-undang Nomor 39 Tahun 1999 tentang Hak Asasi Manusia

Peraturan Pemerintah Nomor 31 Tahun 1999 tentang Pembinaan Dan Pembimbingan Warga Binaan Pemasyarakatan 
Peraturan Pemerintah Nomor 31 Tahun 1999 Tentang Syarat Dan Tata Cara Pelaksanaan Hak Warga Binaan Pemasyarakatan

Peraturan Pemerintah Nomor 32 Tahun 1999 tentang Syarat Dan Tata Cara Pelaksanaan Hak Warga Binaan Pemasyarakatan

Peraturan Pemerintah Nomor 32 Tahun 1999 tentang Syarat Dan Tata Cara Pelaksanaan Hak Warga Binaan Pemasyarakatan

Peraturan Pemerintah Nomor 28 Tahun 2006 tentang Perubahan Atas Peraturan Pemerintah Nomor 32 Tahun 1999 tentang Syarat Dan Tata Cara Pelaksanaan Hak Warga Binaan Pemasyarakatan

Peraturan Pemerintah Nomor 32 Tahun 1999 tentang Syarat Dan Tata Cara Pelaksanaan Hak Warga Binaan Pemasyarakatan

Peraturan Pemerintah Nomor 99 Tahun 2012 tentang Perubahan Kedua Atas Peraturan Pemerintah Nomor 32 Tahun 1999 tentang Syarat Dan Tata Cara Pelaksanaan Hak Warga Binaan Pemasyarakatan

Keputusan Menteri Kehakiman Nomor M.09.KP.10.10 Tahun 1997

Modul Pembimbing Kemasyarakatan, Direktorat Jenderal Pemasyarakatan kementerian Hukum dan HAM RI, September 2021

Naskah AkademikRuu Tentang Perubahan Atas Undang-UndangNomor 12 Tahun 1995 Tentang Pemasyarakatan, Pusat Perencanaan Pembangunan Hukum Nasional Badan Pembinaan Hukum Nasional Kementerian Hukum Dan Hak Asasi Manusia 2013

Penny Naluria Utami, Keadilan Bagi Narapida di Lembaga Pemasyarakatan, Jurnal Penelitian Hukum DE JURE, Volume 17, Nomor 3, September 2017 